\title{
Lincomycin treatment A simple method to differentiate primary and processed transcripts in rice (Oryza sativa L.) chloroplasts
}

\author{
Journal Article \\ Author(s): \\ Yakandawala, Nandadeva; Lupi, Claudio; Bilang, Roland; Potrykus, Ingo \\ Publication date: \\ 2003-09 \\ Permanent link: \\ https://doi.org/10.3929/ethz-b-000052664 \\ Rights / license: \\ In Copyright - Non-Commercial Use Permitted \\ Originally published in:
}

Plant Molecular Biology Reporter 21(3), https://doi.org/10.1007/BF02772799 


\title{
Lincomycin Treatment: A Simple Method to Differentiate Primary and Processed Transcripts in Rice (Oryza sativa L.) Chloroplasts
}

\author{
NANDADEVA YAKANDAWALA*, CLAUDIO LUPI, ROLAND BILANG and \\ INGO POTRYKUS \\ Institute of Plant Sciences, Swiss Federal Institute of Technology (ETH), CH 8092 \\ Zürich, Switzerland
}

\begin{abstract}
Visualizing full-length primary transcripts is helpful in identifying transcription initiation sites and mapping promoter regions of plastid genes and operons. Detection of primary unprocessed transcripts from certain regions of the plastid genome is difficult, and sometimes impossible, because of their rapid and extensive processing. We tested the effect of lincomycin, a prokaryotic protein synthesis inhibiter, on in vivo RNA processing activities in different types of rice plastid. Steady-state levels of RNA produced from the region of the rice plastid genome that includes the $\operatorname{trn} \mathrm{V}$ and $16 \mathrm{~s}$ rRNA genes were analysed by using an RNase protection assay. Results show that sublethal lincomycin levels inhibit RNA processing in leaf chloroplasts and allow the accumulation of primary transcripts, easily distinguishable from processed and processing intermediates. These features were used to identify regions of the $16 \mathrm{r}$ and $t r n \mathrm{~V}$ transcription start sites. This is the first report of the use of lincomycin for mapping plastidic transcripts.
\end{abstract}

Key words: lincomycin, plastid, primary transcript, RNA processing, RNase protection

Abbreviations: 16r, 16S ribosomal RNA; LHC, light-harvesting complex; PCR, polymerase chain reaction.

\section{Introduction}

Most plastid genes are expressed as polycistronic transcripts and undergo a series of RNA processing steps, including RNA editing, intron splicing, site-specific cleavage, and 5'- and 3'-end maturation (Hagemann, 1993; Karcher and Ralph, 2002). Plastidic primary transcripts can be identified with a capping assay. The 5 , ends of primary transcripts can be capped in vitro by using the capping enzyme, guanylyltransferase. Using radioactive $\left(\mathrm{p}^{32}\right) \alpha$ GTP to form the cap structure allows identification of capped transcripts. The capping assay is unproductive for mapping transcripts that are extensively processed or rapidly degraded because results are too complicated to draw any useful conclusions. Therefore, inhibiting processing and allowing accumulation of native primary transcripts are important.

\footnotetext{
*Author for correspondence. Present address: Cereal Research Centre, AAFC, 195 Dafoe Rd, Winnipeg, MB, R3T 2M9, Canada; e-mail: nyakan@agr.gc.ca; fax: +1-204-983 4604 .
} 
We tested lincomycin, an antibiotic known to inhibit prokaryotic and organelle protein synthesis, to investigate its ability to suppress plastid RNA processing. Lincomycin inhibits prokaryotic protein synthesis by interacting with the 23S rRNA/50S subunit of the elongating ribosomal complex in competition with aminoacyl-tRNA (Kallia et al., 1992, 1994; Kallia and Kalpaxix, 1999; Chattopadhyay et al., 1999). Analysis of lincomycin-resistant lines of Chlamydomonas reinhardtii (Harris et al., 1989), Nicotiana plubaginifolia (Cseplo et al., 1993), and Solanum nigrum (Kavanagh et al., 1994) revealed that resistance is conferred by a mutation in the $26 \mathrm{~S}$ rRNA gene in plastids.

Lincomycin has been used numerous times in vitro to inhibit prokaryotic and organelle protein synthesis. It has been used in vivo to study its influence on formation of chromoplast tubules (Emter et al., 1990) and chloroplast ultrastructure elements (Kryloy and Masikevich, 1996), regulation of chlorophyll-protein complex formation (Guseinova et al., 2001), expression of nuclear photosynthetic genes (Sullivan and Gray, 1999, 2002), catabolism of ABA (Cowan and Railton, 1986), and acclimation of the photosynthetic machinery (Tanaka et al., 2000). Lincomycin has also been used to suppress RNA degradation in Cyanobacteria (Komenda et al., 2000) and tobacco chloroplasts (Briat et al., 1987). In this study, we investigated the effect of lincomycin on processing of plastid RNA by analysing $t r n \mathrm{~V}$ and $16 \mathrm{r}$ transcripts in rice proplastids. amyloplasts, and chloroplasts.

\section{Materials and Methods}

\section{Plant growth}

Rice seeds (variety TP309) were dehusked, sterilized in $6 \%$ calcium hypochlorite for $20 \mathrm{~min}$, washed 3 times in sterile distilled water, and germinated on liquid media containing half-strength MS salts and vitamins (Murashige and Skoog, 1962) and $3 \%$ sucrose ( $\mathrm{pH} \mathrm{5.8)}$. Lincomycin was added to the growth media when shoots were $1-2$ in tall.

\section{Tissue culture}

Callus was initiated from 7 - to 10-day-old immature embryos on media containing R2 salts and vitamins (Ohira et al., 1973), 3\% sucrose, and $2 \mathrm{mg} / \mathrm{L}$ 2.4-dichlorophenoxyacetic acid (2,4-D) ( $\mathrm{pH} 5.8$ ) and solidified with $0.6 \%$ agarose. Two-week-old callus was added to liquid R2 media and subcultured weekly. Lincomycin was added to rapidly dividing, friable, suspension culture cells. A range of lincomycin concentrations was tested to determine the level needed to block processing of plastidic RNA but not arrest transcription.

\section{Analysis of RNA}

Leaf, root, and callus samples were collected $2 \mathrm{~d}$ after lincomycin application. Total RNA was isolated using TRlzol Reagent (Invitrogen, Life Technolinstruction). RNA was analysed by using an RNase protection assay. 


\section{Probe preparation}

The plastid DNA sequence from 90728-91408, including the 16S rRNA and $\operatorname{trn} \mathrm{V}$ genes, was isolated by means of PCR, cloned into vector pBSKII(-). linearized with appropriate restriction enzymes, and used to synthesize 3 antisense RNA probes. In vitro transcription reactions were performed using T3 or T7 RNA polymerase with the Riboprobe In Vitro Transcription System (Promega, USA) according to the manufacturer's instructions. ${ }^{32} \mathrm{P}$-rUTP-labeled antisense RNA transcripts were resolved on a $6 \%$ sequencing gel. Transcripts of correct lengths were excised; eluted in a solution containing $0.5 \mathrm{M} \mathrm{NH}_{4}$-acetate, $0.1 \%$ SDS, and $1 \mathrm{mM}$ EDTA; and precipitated with ethanol.

\section{Hybridization and detection}

Twenty micrograms of total RNA was annealed with 50,000 CPM of radiolabeled ribo-probe in $10 \mu \mathrm{L}$ of hybridisation buffer $(80 \%$ formamide, $40 \mathrm{mM}$ PIPES [pH 6.7], $400 \mathrm{mM} \mathrm{NaCl}, 1 \mathrm{mM}$ EDTA). After overnight incubation at $45^{\circ} \mathrm{C}$, hybridization reactions were treated with $10 \mathrm{U}$ of RNase One (Promega, USA) for $40 \mathrm{~min}$ at $30^{\circ} \mathrm{C}$. Reactions were incubated at $37^{\circ} \mathrm{C}$ for $15 \mathrm{~min}$ after adding $2 \mu \mathrm{L}$. each of $10 \%$ SDS and $20 \mathrm{mg} / \mathrm{mL}$ Proteinase $\mathrm{K}(1 \mu \mathrm{g} / \mu \mathrm{L}$, Merck). RNase-protected hybrids were purified by using phenol extraction with ethanol precipitation and dissolved in $5 \mu \mathrm{L}$ of RNA-loading dye $(80 \%$ deionized formamide, $10 \mathrm{mM}$ EDTA $[\mathrm{pH} 8], 1 \mathrm{mg} / \mathrm{mL}$ xylene cyanol FF, $1 \mathrm{mg} / \mathrm{mL}$ bromphenol blue). Samples were resolved on a $6 \%$ sequencing gel at $1600 \mathrm{~V}$ and $35-40$ w. Signals were detected by exposing gels to Kodak Biomax MR film (Eastman Kodak Company, Japan).

\section{Results and Discussion}

\section{Rice plastome sequence and riboprobes}

RNA produced from the $90728-91408$ region of the rice plastome, including the $16 \mathrm{~S}$ rRNA and $t r n \mathrm{~V}$ genes, was selected for analysis. High quality of RNA and several processing sites made this region useful to study. Interpreting RNase protection data from this region was difficult because of the rapid and extensive processing of those transcripts. A similar problem has been encountered in tobacco, and RNase P-like enzymes are thought to be responsible (Vera and Sugiura, 1995). The homologous positions of the 3 antisense RNA probes and the area of the rice plastome that was analysed are schematically represented in Figure ID.

\section{Effect of lincomycin on different plastid types}

The predominant type of plastids in callus, root, and leaves are proplastids, amyloplasts, and chloroplasts, respectively. Total RNA from lincomycin-treated and untreated callus, roots, and leaves was analysed. Initial experiments were conducted to determine a lincomycin concentration that blocked processing of plastidic RNA but did not arrest transcription. Plants and callus were exposed to lincomycin concentrations of $250,500,1000,2000$, and $3000 \mathrm{mg} / \mathrm{L}$.

Amyloplasts in roots and proplastids in callus were unaffected by even the highest lincomycin concentration (Figure 1A). Lincomycin concentrations of 
(A)

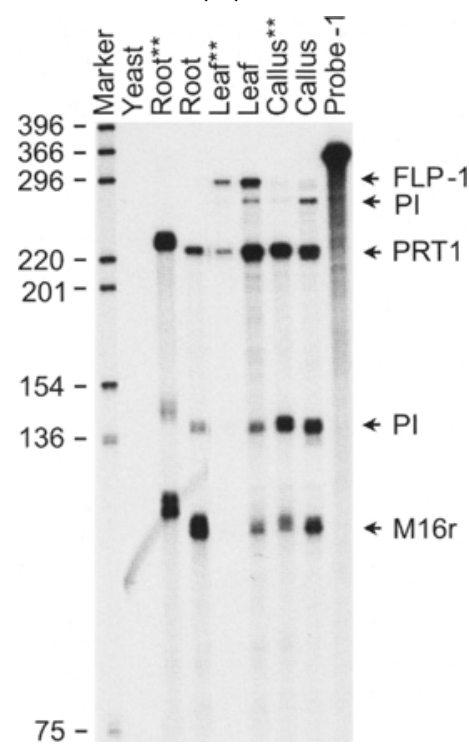

(B)

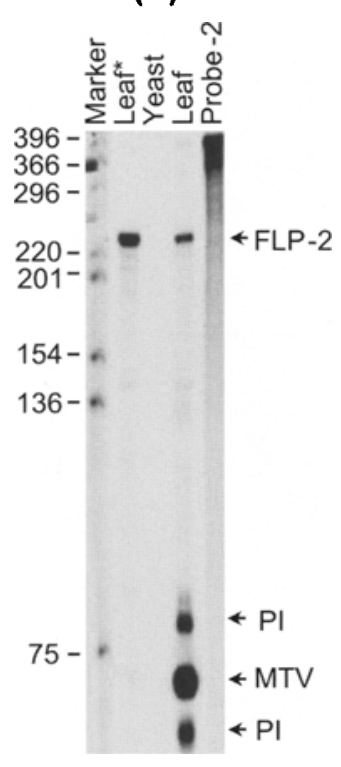

(C)

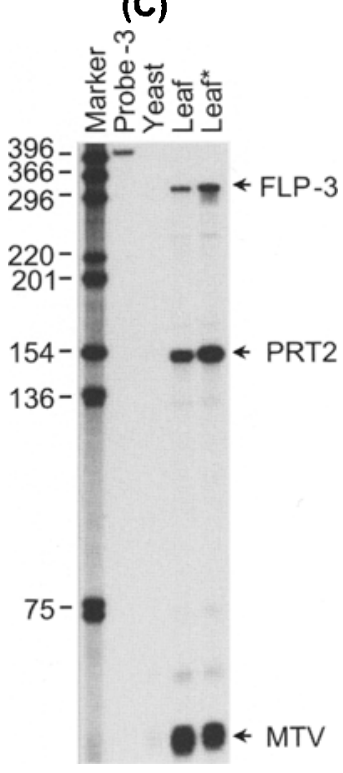

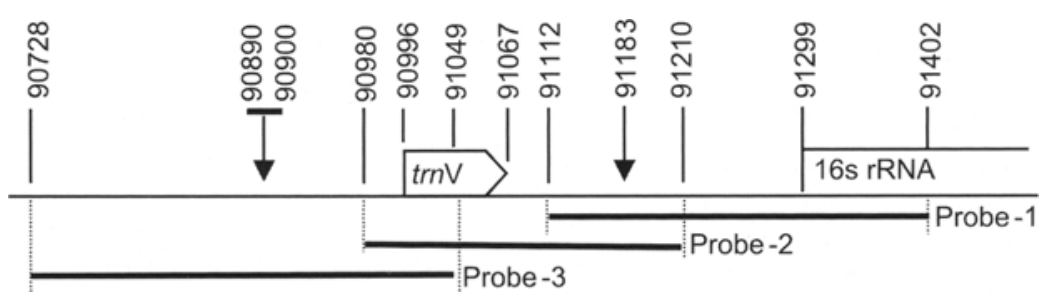

Figure 1 . Changes in steady-state concentrations of $16 \mathrm{r}$ and $t r n \mathrm{~V}$ transcripts in rice plastids. A, B, and $C$ are RNase protection assays with probes 1,2 , and 3, respectively. RNase-protected transcripts are indicated with horizontal arrows and labeled FL.P 1, 2, and 3 for full-length-protected fragments: PRT1 and PRT2 for $16 \mathrm{r}$ and $t r n \mathrm{~V}$ primary transcripts; PI for the processing intermediate; M16r for the mature 16r transcript; and MTV for the mature $t r n V$ transcript. Ianes are labeled to indicate the source of RNA used. Single (*) and double (**) asterisks indicate that the source of RNA has been treated with $1000 \mathrm{mg} / \mathrm{L}$ and $3000 \mathrm{mg} / \mathrm{L}$ of lincomycin, respectively. D schematically represents the area of the rice plastome that was analyzed and the positions of the probes. Plastome positions are numbered. The published 16r transcription start site and an approximate 10-bp region of the $\operatorname{trn} \mathrm{V}$ transcription start site indicated with arrow heads in D correspond to the 5 ' ends of the transcripts PRT-1 and PRT-2 in (A) and (C), respectively.

$1000 \mathrm{mg} / \mathrm{L}$ and more stopped RNA processing in chloroplasts. However, the effect of lincomycin was obscured when RNA was isolated from the whole leaf (data not shown). The inhibitory effect of lincomycin on RNA processing was only detected when RNA samples were isolated from leaves with basal meristematic regions removed. Inconsistent results generated by RNA samples 
isolated from whole-leaf material of lincomycin-treated plants could be due to the contribution of RNA from proplastids of the basal meristematic region.

Overall reduction of steady-state levels of $16 \mathrm{r}$ and $\operatorname{trnV}$ transcripts in leaf chloroplasts was observed when plants were treated with $3000 \mathrm{mg} / \mathrm{L}$ of lincomycin (Figure 1A). Similar observations were made when lincomycin treatment was continued for more than $4 \mathrm{~d}$ at a concentration of $1000 \mathrm{mg} / \mathrm{L}$, which led to chlorosis in leaves (data not shown). Therefore, $1000 \mathrm{mg} / \mathrm{L}$ of lincomycin treatment for $2 \mathrm{~d}$ was suitable to maintain transcription and inhibit RNA processing.

\section{Identification of primary transcripts}

Primary transcripts can be distinguished from processed transcripts by comparing the signal intensities of RNase-protected transcripts derived from lincomycin-treated and untreated tissues. Full-length-protected fragments (FLP1, FLP2, FLP3) that are 5' short primary unprocessed transcripts and the primary transcripts containing native 5' ends (PRT1 and PRT2) are more intense or unchanged, while those of mature transcripts (M16r, MTV) and processing intermediates (PI) are weakened or disappear when treated with lincomycin (Figures 1A-C). The PRT1 and PRT2 (Figures 1A, 1C) that were shown to contain native $5^{\prime}$ ends were confirmed with an in vitro capping assay (Nandadeva, 1999).

Native 5 ' ends of plastidic primary transcripts are conventionally identified by means of in vitro capping assays. Optimum conditions for a particular capping reaction must be empirically determined. Reaction volume, RNA-to-enzyme ratio, and concentration of $\left(\alpha-{ }^{32} \mathrm{p}\right)$ GTP are critical parameters. Detecting low abundant primary transcripts might be impossible because of the signal weakness of capped transcripts. In addition, the capping reaction does not always give reproducible and consistent results. Inconsistent results, high cost, high amount of radioactive nucleotides used per reaction $(200-500 \mu \mathrm{Ci})$, and related health hazards are strong reasons for improving the technique or finding alternatives to in vitro capping. Therefore, using lincomycin-treated RNA for the RNase protection assay can potentially replace the in vitro capping assay.

\section{Accumulation of primary transcript}

Studies conducted in Escherichia coli K-12 revealed that sublethal lincomycin concentrations do not stimulate the production of mRNA of the beta lactamase gene carried on plasmid pBR322 but slow its degradation rate and increase its stability (Matsushita, 1988; Matsushita et al., 1989). At the level of protein synthesis. the inhibitory effect of lincomycin is contradictory for some proteins. Synthesis of photosynthetic protein P700 LHC I in wheat and LHCP II in maize was not affected by lincomycin treatment (Guseinova et al., 2001; Sarvari et al., 1989). Therefore, one can assume that preferential inhibition of processing enzyme synthesis prior to RNA polymerase synthesis at subinhibitory levels of lincomycin might lead to the accumulation of primary transcripts in plastids. On the basis of this assumption and our results, we assume that, at $1000 \mathrm{mg} / \mathrm{L}$ of lincomycin, synthesis of chloroplast RNA polymerases is not inhibited. We observed a reduction of steady-state levels of $16 \mathrm{r}$ and $\operatorname{tr} \mathrm{V}$ transcripts at high 
lincomycin concentrations, indicating that chloroplast transcriptional activities were affected.

The differential effect of lincomycin on different plastid types may be due to factors such as (1) the presence of molecules other than the transcription initiation complex that binds lincomycin, (2) differences in the rate of synthesis and decay of processing enzymes and RNA polymerases, and (3) inefficient transport of lincomycin.

\section{Conclusion}

Using 3 overlapping probes, we located 2 transcription start sites, one of which has already been documented (Silhavy and Maliga, 1998). Our method is useful for visualizing primary transcripts and locating promoter regions and transcription start sites in rice chloroplasts. Lincomycin is useful for mapping regions that are extensively and rapidly processed. It can also potentially replace the capping assay, which is expensive and requires substantial amounts of $\left(\mathrm{p}^{32}\right) \alpha$ GTP. Our experimental conditions also provide guidelines for using lincomycin for mapping plastid transcripts in other plant species.

\section{Acknowledgments}

The authors are grateful to the Swiss National Foundation for funding this work.

\section{References}

Briat JF, Seyer BS, and Lescure AM (1987) In vitro transcription initiation of the rDNA operon of spinach chloroplast by a highly purified soluble homologous RNA polymerase. Curr Genet 11: 259-263.

Chattopadhyay S, Pal S, Pal D, Sarker D. Chandra S, and Das GC (1999) Protein folding in Escherichia coli: role of $23 \mathrm{~S}$ ribosomal RNA. Biochimica et Biophysica Acta 1429: 293-298.

Cowan AK and Railton ID (1986) Chlroplasts and the biosynthesis and catabolism of abcisic acid. J Plant Growth Reg 4: 211-224.

Cseplo A, Eigel L. Horvath GV, Medgyesy P, Herrmann RG, and Koop HU (1993) Subcellular location of lincomycin resistance in Nicotiana mutants. Mol Gen Genet 236: $163-170$.

Emter O, Falk H. and Sitte P (1990) Specific carotenoids and proteins as prerequisites for chromoplast tubule formation. Protoplasma 157: 128-135.

Guseinova IM, Sulcimanov SY, and Aliev JA (2001) Regulation of chlorophyll-protein complex formation and assembly in wheat thylakoid membrane. J Biochem Mol Biol 34: $496-501$.

Hagemann R (1993) Recent molecular and cytological aspects of plastid genetics. Biologisches Zentrablatt 112: 244-287.

Harris EH, Burkhart BD. Gillham NW, and Boynton JC (1989) Antibiotic resistance mutation in the chloroplast $16 \mathrm{~S}$ and $23 \mathrm{~S}$ ribosomal RNA genes of Chamydomonas reinhardtii correlation of genetic and physical maps of the chloroplast genome. Genetics 123: 281-292. 
Kallia RS and Kalpaxix DL (1999) Slow sequential conformational changes in Escherichia coli ribosomes induced by lincomycin: Kinetic evidence. Molecular Pharmocol 56: 1042-1046.

Kallia RS, Kalpaxis DL, and Coutsogeorgopoulos C (1992) Slow onset inhibition of ribosomal peptidyltransferase by lincomycin. Arch Biochem Biophys 298: 332-229.

Kallia RS. Kalpaxis DL, and Coutsogeorgopoulos C (1994) New aspects of the kinetics of inhibition by lincomycin of peptide bond formation. Mol Pharmacol 46: 1009-1014.

Karcher D and Ralph B (2002) Temperature sensitivity of RNA editing and intron splicing reaction in the plastid ndhB transcript. Curr Genet 41: 48-52.

Kavanagh TA, O'Driscoll KM. McCabe PF, and Dix PJ (1994) Mutation conferring lincomycin. spectinomycin, and streptomycin resistance in Solanum nigrum are located in three different chloroplast genes. Mol Gen Genet 242: 67.5-686.

Komenda J. Hassan HAG, Diner BA, Debus RJ. Barber J, and Nixen PJ (2000) Degradation of photosystem II D1 and D2 proteins in different strains of the cyanobacterium synechocyctis PCC 6803 varying with respect to the type and level of psbA transcripts. Plant Mol Biol 42: 6.35-645.

Kryloy OA and Masikevich YG (1996) The influence of lincomycin and cycloheximide on formation of chloroplast ultrastructure elements in heterotic maize hybrids and their initial forms. Vyestsi-Akademii-Navuk-Byelarusi-Sycryya-Biyalahichnykh-navuk. 3: 51-55.

Matsushita $O$ (1988) Mechanism of stimulation by lincomycin of the beta lactamase production in Escherichia coli. Okayama Igakkai Zasshi. 100: 455-464.

Matsushita O. Okabe A, Hayashi H, and Kanemasa Y (1989) Lincomycin increases the half-life of beta lactamase messenger RNA. Antimicrob Agents and Chemother 33: 805-809.

Murashige T and Skoog F (1962) A revised medium for rapid growth and bioassays with tobacco tissue culture. Physiol Plant 15: 473-497.

Nandadeva Y (1999) Towards plastid transformation in rice. PhD Thesis. Institute of Plant Sciences, Swiss Federal Institute of Technology, Zurich, Switzerland.

Ohira K, Ojima K, and Fujiwara A (1973) Studies on the nutrition of rice cell culture, I: a simple, defined medium for rapid growth in suspension culture. Plant Cell Physiol 14: 1313-1121.

Sarvari E. Nyitrai P, and Keresztes A (1989) Relative accumulation of LHCP II in mesophyll plastids of intermittently illuminated maize seedlings under lincomycin treatment. Biochemic und Physiologic der Pflanzen BPP 184: 37-47.

Silhavy D and Maliga P (1998) Plastid promoter utilisation in a rice embryogenic cell culture. Curr Genet 34: 67-70.

Sullivan JA and Gray JC (1999) Plastid translation is required for the expression of nuclear photosynthesis genes in the dark and in roots of pea lip I mutant. Plant Cell 11: 901-910.

Sullivan JA and Gray JC (2002) Multiple plastid signals regulate the expression of the pea plastocyanin gene in pea and transgenic tobacco plants. Plant J 32: 763-774.

Tanaka Y, Nishiyama Y, and Murata N (2000) Acclimation of the photosynthetic machinery to high temperature in Chlamydomonas reinhardtii requires synthesis de novo of proteins encoded by the nuclear and chloroplast genomes. Plant Physiol 124: 441-449.

Vera $\Lambda$ and Sugiura M (1995) Chloroplast rRNA transcription from structurally different tandem promoters: an additional novel-type promoter. Curr Genet 27: 280-284. 